\title{
Is Customer Satisfaction Driving Revenue - A Longitudinal Analysis With Evidence From The Banking Industry
}

Gerhard Winkler, (Email: gerhard.winkler@wu-wien.ac.at), Vienna University, Austria Markus S. Schwaiger, (Email: markus.schwaiger@wu-wien.ac.at), Vienna University, Austria

\begin{abstract}
:
The connection between customer satisfaction and the financial performance of companies has been under academic scrutiny for quite some time. Evidence regarding the long term impact of customer satisfaction is however relatively scarce. Furthermore, research has so far often neglected potential industry idiosyncrasies in estimating the consequences of changes in customer satisfaction. We provide an insight into the overall long run impact of customer satisfaction on operating revenues based on a longitudinal dataset for the Austrian retail banking industry. Our results corroborate the intuition of a positive long run effect of satisfaction on revenues. We can show, that a time lag of 1,5 years has to elapse for satisfaction to have a positive impact on sales.
\end{abstract}

\section{Introduction}

$T$ he growing body of literature dedicated to customer satisfaction dating back as far as the late $70 \mathrm{~s}^{1}$ documents the relevance of satisfaction in modern marketing theory. Intense competition in a saturated market environment has furthermore led to a broad acceptance of the importance of customer satisfaction in practice. $^{2}$

In the context of shareholder-value orientated leadership two questions have to be asked with regards to customer satisfaction: First, whether customer satisfaction has an impact on revenues at all and, if yes, how this impact can be operationalized in order to provide a (quantitative) basis for managerial decisions. ${ }^{3}$

However, only a relatively narrow branch of research has investigated the relationship between customer satisfaction and the financial performance of companies. ${ }^{4}$ Furthermore, a lot of the existing evidence is anecdotal in the sense of being based on case studies.

Relying on an analysis of the PIMS (Profit Impact of Marketing Strategy)-dataset Buzzel/Gale (1987) were the first to prove a positive impact of quality on profits. Nelson et al. (1992) also find a positive link between the perception of quality of patients and the financial performance of a hospital. The case of Sears has been studied by

\footnotetext{
${ }^{1}$ See Oliver (1977) and TARP (1979).

${ }^{2}$ Compare Shoultz (1989) and Loro (1992).

${ }^{3}$ See Fischer/Hermann/Huber (2001), p. $1162 \mathrm{ff}$.

${ }^{4}$ Compare Anderson/Fornell/Rust (1997), Fornell (1992), Anderson/Fornell/Lehmann (1994), Homburg (1998), Bernhardt /Donthu/Kennet (2000) and Rust/Zahorik/Keiningham (1995).
} 
Rucci/Kirn/Quinn (1998), who discovered a (positive) relation between "customer impression" and "revenue growth". Evidence from Xerox confirms the Sears experience. ${ }^{5}$ Further rather anecdotal evidence on a positive impact of increased customer satisfaction can be found in Dull (1998) for the paper industry, Keiningham/Zahorik/Rust (1994) and Licata/Weber/Reed (1998) for the banking industry and Birchard (1994) on Whirlpool.

Anderson/Fornell/Lehmann (1994) provide an important contribution for quantifying the impact of satisfaction on profits. ${ }^{6}$ Their empirical investigation is based on a dataset of 77 Swedish companies from various industries and shows that satisfaction (SAT) has significant and sizeable contemporaneous explanatory power for a company's return on investment (ROI). As it seems quite plausible, that the reaction of profits to changes in customer satisfaction may vary with industries, these results however have to be treated with caution. ${ }^{7}$ The cross sectional character of the estimation - SAT at time $t$ explains ROI at time $t$-also commends caution in the interpretation of results - satisfaction may very well have lagged effects on profits. ${ }^{8}$ A longitudinal estimation of the influence of customer satisfaction has thus been widely recommended. ${ }^{9}$ Bernhardt/Donthu/Kennet (2000) have taken up the idea and provided evidence on the connection between customer satisfaction and various financial ratios of an American fast food chain based on a dataset of 472 restaurants over a one year observation period. Partitioning of the sample into four sub-periods allowed them to detect a significant correlation between satisfaction, lagged by one period, and sales.

Empirical results are however far from being unambiguous as for the sign of the effect of customer satisfaction. Evidence provided by the consulting firms A.T.Kearney and Arthur D. Little paints a gloomy picture. In two separate studies, they conclude that (1) in $80 \%$ of cases out of more than 100 British companies "no significant impact as a result of TQM" has been recorded, and (2) nearly 2/3 of 500 U.S companies registered "zero competitive gains" out of improving quality. ${ }^{10}$ The results of Aaker/Jacobson (1994) also seem to bear out the intuition that "customer service-quality perceptions and satisfaction are sometimes, but not always, reflected in profits." Griliches (1971) already noted two decades earlier that investment in improved quality may have detrimental effects on a company's cost structure. Tornow/Wiley (1991) even show, that customer satisfaction and profits display a negative correlation. ${ }^{12}$

What can be said in conclusion therefore is that the evidence on the link between customer satisfaction and revenues/profits is encouraging, but far from clear. The problem of collecting a reliable, consistent and sufficiently large data set has furthermore led to a lot of research taking the form of case study-evidence. Rather few papers provide insights into the quantitative relation between the two variables. Even these studies - for lack of appropriate data - often rely on data from several industries, which, due to industry idiosyncrasies can only provide a blurry picture of the consequences of customer satisfaction on profits. Furthermore, up to now, only one study (Bernhardt/Donthu/Kennet (2000)) has attempted to address the effects of satisfaction on profits over time by the use of longitudinal data, although their dataset comprises just 4 quarters (1 year). The real importance of customer satisfaction can however only be fully captured by an examination of the relationship between satisfaction and revenues over a long-term perspective.

\footnotetext{
${ }^{5}$ See Carr (1992).

${ }^{6}$ See also Fornell (1992), as well as Rust/Zahorik/Keiningham (1995) and Fischer/Hermann/Huber (2001), who try to quantify the relation by way of ratios, e.g. the ROQ (Return on Quality).

${ }^{7}$ See Anderson/Fornell/Rust (1997) who, focussing on the relation between customer satisfaction and productivity, find differences in ROI elasticities to changes in customer satisfaction between the production and the service industry.

${ }^{8}$ See Rust/Zahorik (1993).

${ }^{9}$ See LaBarbera/Mazursky (1983), or Zeithaml/Parasuraman/Berry (1990).

${ }^{10}$ The Economist (1992).

${ }^{11}$ Schneider (1991), p. 154.

${ }^{12}$ See also Hill (1993) for anecdotal evidence in the same line on Wallace Company winning the Malcolm Baldridge National Quality Award in 1990 and going bust just two years later.
} 
By using a longitudinal data set from a single industry (Austrian retail banks) dating back 15 years, we are able to give a detailed quantitative analysis of the influence of satisfaction on revenues for the banking industry. The longitudinal characteristics of our panel enables us to investigate the existence of time lags driving the relation between the two variables. The paper therefore answers the questions, whether there is a relation between customer satisfaction and revenues, how this relation can be quantified, how long it takes for satisfaction to have an effect on the sales figures of a bank and how the effects of customer satisfaction on revenues change in the course of time. Answering these questions should give valuable support to management decisions in quality management and marketing in general.

\section{Theoretical Framework}

Understanding the links between customer satisfaction and revenues is a prerequisite in order to be able to formulate hypotheses on the existence, intensity, shape and time dimension of this relationship. This however implies identifying those factors - henceforth referred to as "mediating variables" or "mediators" - establishing a link between satisfaction and performance:

- Repurchasing intentions

The probability of choosing the same company again is higher for customers satisfied than for those unsatisfied with past consumption. ${ }^{13}$ The positive relation between the repurchase rate and satisfaction provides the company with a stable source of sales, bound to be very valuable - especially when seen over a sufficiently long horizon. ${ }^{14}$ It has to be noted however, that the effect of repurchasing intentions on sales may very well take time to be seen - customers who have just bought a product/service that changed their satisfaction will possibly not experience a need for the same product/service again for some time.

- Cross-selling

Satisfied customers are however not only valuable for their higher repurchasing intentions, but they are also more likely to consume other products/services from the same supplier. ${ }^{15}$

- Price elasticity

Furthermore, empirical evidence has confirmed the intuition that customer satisfaction decreases price elasticity. ${ }^{16}$ Especially reward-programs combined with a high level of service quality can help induce customers to put less emphasis on price considerations. ${ }^{17}$ Therefore satisfaction can be used to increase pricing power and to immunize against poaching initiatives of competitors based on aggressive pricing. ${ }^{18}$

\footnotetext{
${ }^{13}$ See Rust/Zahorik/Keiningham (1994), (1995) and Fornell (1992).

${ }^{14}$ See Thomas (1998).

${ }^{15}$ See Rose (1990) and for evidence from the automotive industry Hermann/Johnson (1999), Johnson (1998) and (1995).

${ }^{16}$ See e.g. Anderson(1996), Garvin (1988) and Downling/Uncles (1997), p. 71ff. for contrary evidence.

${ }^{17}$ See Mohs (1999).

${ }^{18}$ See Anderson/Sullivan (1993), p. $127 \mathrm{ff}$.
} 
- Recommendation effect

Customer satisfaction is however not only a valuable tool of "defensive marketing" intended to keep the existing customer base, but is equally valuable as a means of a marketing strategy intended to win new customers. ${ }^{19}$ Advertising by positive word of mouth helps improve the overall reputation of a company. This can be beneficial in maintaining and/or establishing relationships with stakeholders (suppliers, workers, distributors). Positive word of mouth can furthermore help position services/products in a high quality range ${ }^{20}$ as well as help counter negative external shocks. A case in point for the importance of customer satisfaction in this respect is the research undertaken by the "Technical Assistance Research Program (TARP)",21, which has shown that unsatisfied customers tend to share their experiences with 9 other people whereas satisfied customers recommend their supplier to an average of 3 persons.

Note that both sales price and volume are affected by the above mediators. Whereas price elasticity is going to influence the product/service price, the other three mediating variables have an impact on the sales volume. Figure 1 summarizes the hypothesized relationship between satisfaction and revenues:

Figure 1: The link between satisfaction and revenues

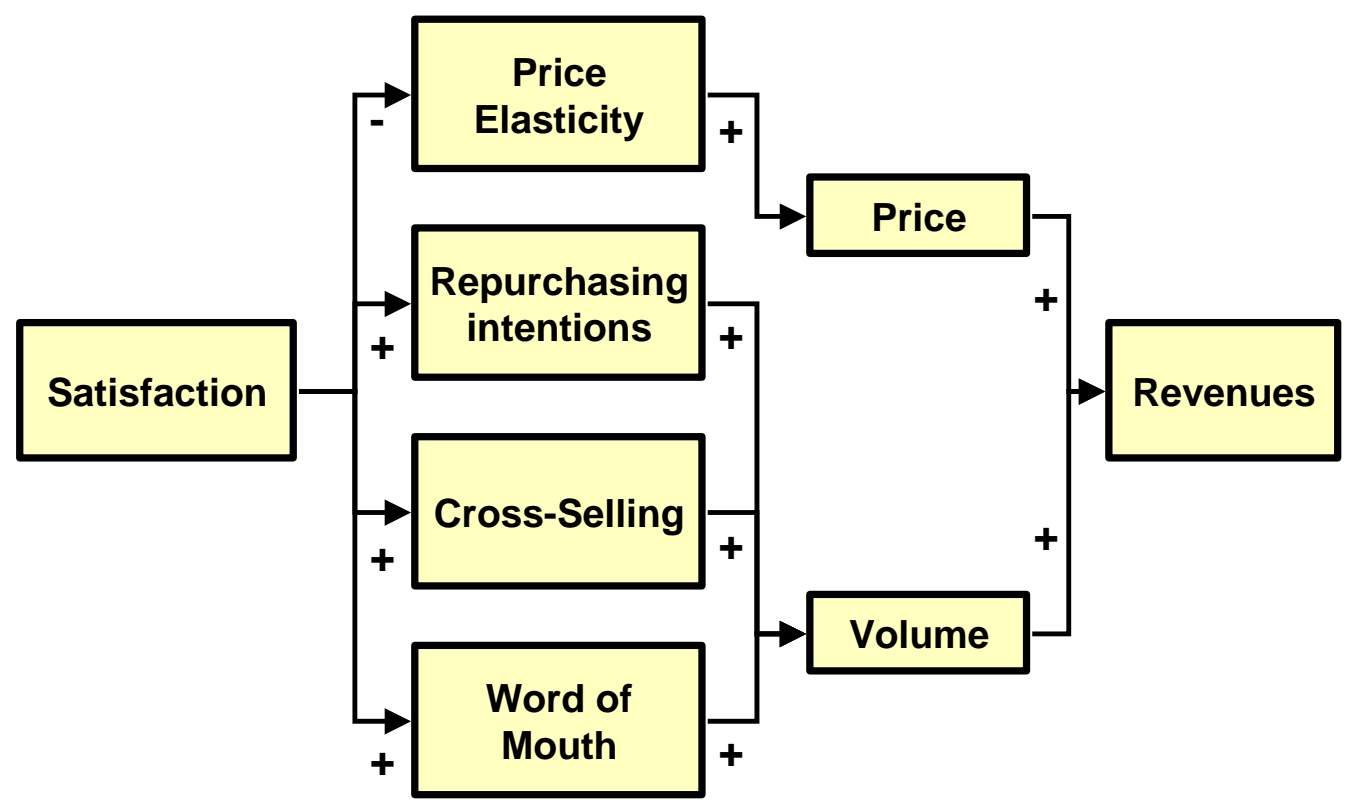

With these well-known facts in mind we believe that higher customer satisfaction should lead to a rise in a company's revenues. However, since most of the positive consequences of high customer satisfactions enumerated above refer to behavioral intentions, we expect that it may take some time until these intentions translate into consumer actions and have an effect on sales.

\footnotetext{
${ }^{19}$ See Rust/Zahorik/Keiningham (1995), p. 59.

${ }^{20}$ See DeSarbo/Huff/Roladelli/Jungwhan (1994).

${ }^{21}$ See TARP (1979), (1981) and (1986).
} 
Formally, this hypothesis can be expressed by the following equation:

$$
\text { Revenues }_{t}=f\left(\text { Satisfaction }_{t-x}, \theta_{t}\right) \quad x=1, \ldots, T
$$

The equation reflects the fact that revenues at time $t$ are positively affected by past customer satisfaction, as well as other factors, e.g. general economic conditions, firm-specific factors and an error component, captured by the vector $\theta_{t}$

\section{Data}

Our dataset consists of semiannual revenue and satisfaction data over 15 years - from 1988 to 2002 - for four Austrian retail banks. Operating revenue data was obtained from quarterly and annual reports of the corresponding banks provided by the Austrian Central-Bank (OeNB), as was the data for the overall Austrian Banking system. ${ }^{22}$

Generally speaking, longitudinal satisfaction data is very hard to obtain. Only quite recently customer satisfaction indices have been introduced and calculated - the Swedish Customer Satisfaction Barometer in 1990, the Deutsche Kundenbarometer in 1992 or the American Customer Satisfaction Index in $1994 .^{23}$ The satisfaction index we use describes the average overall satisfaction per bank transformed into a 0 to 100 scale. It is based on direct customer surveys of overall satisfaction with the bank in question. The index stems from interviews conducted by an Austrian retail bank covering its own clients and those of its three main competitors. Approximately 4.000 semiannual interviews were held at each point in time, where customers were asked to evaluate the overall satisfaction with their bank on a seven-point scale. The interview-sample at each point in time reflected the market share of each of the four banks. Average overall satisfaction is defined as the mean per bank of all satisfaction evaluations resulting from the survey of the bank's clients. The constant size of the sample over time and the inclusion of market share data into the sample selection guarantees a representative and comparable data set for overall customer satisfaction.

We therefore use an explicitly one-dimensional characterization of customer satisfaction, as done in numerous other papers. $^{24}$ This concept however has also been subject to critical comments ${ }^{25}$, especially in papers focussing on the components and different dimensions of satisfaction. In this regard, one-dimensional data will almost certainly be of limited use for diagnostic means. ${ }^{26} \mathrm{~A}$ balanced view of multi- and single dimensional definitions however has to take the intended use of the satisfaction data into account. ${ }^{27}$ As other authors also rely on single dimensional satisfaction data when investigating the link between satisfaction and profits ${ }^{28}$, it is considered appropriate for the purpose of this paper too.

\section{Specification}

Having discussed the question why and how satisfying customers should affect revenues, we can now move on and specify a model for the econometric analysis of the hypothesized relationship between customer satisfaction and revenues.

\footnotetext{
${ }^{22}$ See OeNB (1989a); OeNB (1989b); OeNB (1990a); OeNB (1990b); OeNB (1991a); OeNB (1991b); OeNB (1992a); OeNB (1992b); OeNB (1993a); OeNB (1993b); OeNB (1994a); OeNB (1994b); OeNB (1995a); OeNB (1995b); OeNB (1996a); OeNB (1996b); OeNB (1997a); OeNB (1997b); OeNB (1998a); OeNB (1998b); OeNB (1999a); OeNB (1999b); OeNB (2000a); OeNB (2000b); OeNB (2001a).

${ }^{23}$ See Fornell/Johnson/Anderson/Cha/Bryant (1996).

${ }^{24}$ See Westbrook (1980), Swan/Martin (1981) or Fornell (1992).

${ }^{25}$ See Fishbein/Ajzen (1975), p. 365ff., Mittal/Ross/Baldasare (1998), p. 33 ff. and Mittal/Kamakura (2001), p. 133.

${ }^{26}$ Runow (1982), p. $26 \mathrm{ff}$.

${ }^{27}$ See Peterson/Wilson (1992).

${ }^{28}$ See e.g. Anderson/ Fornell/Lehmann (1994) and Bernhardt/Donthu/Kennet (2000).
} 
In keeping with the arguments advanced in the previous sections, revenues $r_{i, t}$ of bank $i$ at time $t$ are influenced by lagged customer satisfaction $s_{i, t-k}$. As the dynamics, and therefore $k$, are unknown we start off with an unrestricted finite distributed lag model. ${ }^{29}$ Additionally, the revenues are affected by a set of other factors $\theta_{t}$, that depend on the general state of the economy at time $t$ and on a wide variety of firm specific influences that could be both time-dependent (e.g. operative management plans) or time-invariant (e.g. strategic resources of the firm like management qualifications, technological resources etc.).

It is well known, however, that an omission of relevant explanatory variables leads to inconsistent and seriously biased estimators, if the orthogonality conditions do not hold and any of the omitted variables is correlated with any of the observable regressors. ${ }^{30}$ We tackle this problem in several ways: First the aggregated revenues of the whole industry at time $t$ less the contemporaneous sum of the revenues of the four banks in question, $a_{t}$, are added as a proxy for the general economic conditions governing the banking industry. Second, following a common technique to account for possible unobservable time-variant firm-specific effects and for heterogeneity in the crosssection of banks, a lagged dependent variable $r_{i, t-1}$ is added as an additional regressor. ${ }^{31}$ Thus the model becomes an autoregressive distributed lag model $\operatorname{ARDL}(1, q){ }^{32}$ This is to say that although the number of satisfaction terms is $q$ and therefore finite, the revenues $r_{i, t}$ depend on the $s_{i}$ back to the indefinite past via $r_{i, t-1}$. Therefore this formulation reflects the expected persistence of the benefits of customer satisfaction for the firm: ${ }^{33}$ Third, to deal with unobserved time-invariant firm specific effects, the error in the model is assumed to contain a cross-section specific unobserved effect $e_{i}$, as well as random noise $u_{i, t}{ }^{34}$ elasticities.

Logarithms are taken of each variable, which enables us to interpret the estimated coefficients as

Thus the basic model based on our theoretical framework is given by:

$$
\ln \left(r_{i, t}\right)=\sum_{k=1}^{q} \beta_{k} \ln \left(s_{i, t-k}\right)+\beta_{q+1} \ln \left(a_{t}\right)+\beta_{q+2} \ln \left(r_{i, t-1}\right)+e_{i}+u_{i, t}
$$

With a balanced panel of $N=4$ banks and $T=30, T$ is sufficiently large relative to $N$. Therefore $T \rightarrow \infty$ asymptotics are more appropriate, and the framework becomes multiple time series analysis. ${ }^{35}$ However, whereas $N \rightarrow \infty$ asymptotics impose no restrictions on the time series persistence in the data, for $T \rightarrow \infty$ the data must be stationary to produce consistent estimates, otherwise the regression coefficients are well known to have nondegenerate limit distributions and the regression is characterized as spurious. ${ }^{36} \mathrm{We}$ therefore conduct Augmented-Dickey-Fuller Tests on each of the individual series to test for an unit-root. The test statistics for the null-hypothesis of an unit-root are shown in Table 1. It can be seen that the results of the stationarity tests cast doubt over the stability of parameters over time. All of the series are non-stationary in levels and taking the first differences produces stationary processes.

\footnotetext{
${ }^{29}$ See Greene (2000), p. 717.

${ }^{30}$ See Greene (2000), p. 334, and Wooldridge (2002), p. 62.

${ }^{31}$ See Amemiya (1985), Boulding (1990), Anderson/Fornell/Lehmann (1994), Nair-Reichert/Weinhold (2001), Wooldridge (2000), p. 289, and Wooldridge (2002), p. 493.

${ }^{32}$ See Greene (2000), p. 725, Harvey (1990), and Jorgenson (1966), who labels this model a rational lag model.

${ }^{33}$ See Anderson/Hsiao (1982), p. 61, and Wooldridge (2002), p. 493.

${ }^{34}$ See Greene (2000), p. 582, Wooldridge (2002), p. 248.

${ }^{35}$ See Wooldridge (2002), p. 250, Greene (2000), p. 592, and Grunfeld/Griliches (1960) as an early example.

${ }^{36}$ See Granger/Newbold (1974), and Phillips (1986).
} 
Table 1: Test statistics for ADF-unit-root-tests on each individual series; *** denotes significance at the $1 \%$ level

\begin{tabular}{|ccccccc|}
\hline \multicolumn{7}{c|}{ Test Statistics for Augmented Dickey Fuller Tests } \\
\hline $\boldsymbol{i}$ & $\ln \left(\boldsymbol{r}_{\boldsymbol{i}}\right)$ & $\Delta \ln \left(\boldsymbol{r}_{\boldsymbol{i}}\right)$ & $\ln \left(\boldsymbol{s}_{\boldsymbol{i}}\right)$ & $\Delta \ln \left(\mathbf{s}_{\boldsymbol{i}}\right)$ & $\ln (\boldsymbol{a})$ & $\Delta \ln (\boldsymbol{a})$ \\
$\mathbf{1}$ & 2,04 & $-4,25 * * *$ & $-0,19$ & $-7,42 * * *$ & & \\
$\mathbf{2}$ & 2,61 & $-3,28 * * *$ & 0,17 & $-5,18 * * *$ & & \\
$\mathbf{3}$ & 1,19 & $-3,09 * * *$ & 0,47 & $-7,80 * * *$ & 2,39 & $-3,07 * * *$ \\
$\mathbf{4}$ & 3,55 & $-3,07 * * *$ & 0,05 & $-7,49 * * *$ & & \\
\hline
\end{tabular}

Since all the series are integrated of order one, first differencing is the common and appropriate transformation of the basic model given in (2). ${ }^{37}$ The model in its first difference specification is an unrestricted finite distributed lag model given by

$$
\Delta \ln \left(r_{i, t}\right)=\sum_{k=1}^{q} \beta_{k} \Delta \ln \left(s_{i, t-k}\right)+\beta_{q+1} \Delta \ln \left(a_{t}\right)+\varepsilon_{i, t}
$$

and is therefore an extension of one of the models, Anderson/Fornel1/Lehmann (1994) use in their analysis.

Entering all the variables in equation (3) in their logarithmic, first-difference form has several advantages: First, it allows the variables to be interpreted in terms of growth rates without changing any of the predictions made above about the expected signs of the coefficients. Second, as already mentioned the regression coefficients are elasticities and measure the relative increase in revenue growth induced by a one percent growth in satisfaction growth with an impact multiplier $\beta_{1}$ capturing the immediate effect and $\sum_{k=1}^{q} \beta_{k}$ the long-run propensity. Finally, through the formulation of the relationship between revenues and customer satisfaction in terms of growth rates as in (3), the law of diminishing marginal returns is implicitly accounted for. It is reasonable to assume that the economic benefits of raising customer satisfaction decline and eventually die out as the level of average satisfaction of all customers becomes higher: Since the coefficients of the regression model can be interpreted as elasticities the first $\beta_{1}, \ldots, \beta_{k}$ parameters measure the impact a one-percentage rise in the growth rate of customer satisfaction has on the growth of revenues. Seen the other way round, in order to achieve a one percent increase in revenues in the longrun a bank needs a rise in satisfaction of $\frac{1}{\sum_{k=1}^{q} \beta_{k}}$. This however is easier to achieve for a bank operating on a lower absolute satisfaction level than for a bank with a high absolute overall-satisfaction as measured by the index.

Additionally, transforming the data through first differences as in (3) is a common correction for controlling for unobservables and heterogeneity in cross-sectional time-series data. A second way to account for individual heterogeneity, that is applied here, is to allow the variance to vary with the cross-sections unit. ${ }^{38}$ As the explanatory variables in the model are not jointly determined with the dependent variable according to our theoretical framework, there is no simultaneity bias and we can use feasible GLS to estimate the parameters of interest consistently for $T \rightarrow \infty .^{39}$

\footnotetext{
${ }^{37}$ See Greene (2000), p. 778, and Wooldridge (2000), p. 585.

${ }^{38}$ See Holtz-Eakin/Newey/Rosen (1988), p. 1372.

${ }^{39}$ See Greene (2000), p.596, and Wooldridge (2000), p. 353.
} 


\section{Estimation and Results}

Since the lag length of the unrestricted finite distributed lag model as in (3) is not known a priori we determine it using the Akaike information criterion (AIC) as well as the Schwarz criterion (SC), which are two alternative fit measures that have been suggested for this purpose. ${ }^{40}$

Table 2: Determination of lag length on the basis of AIC and SC;

* denotes the model selected on the basis of the respective criterion

\begin{tabular}{|cccccccccc|}
\hline \multicolumn{10}{|c|}{ Determination of lag length } \\
\hline K & $\mathbf{0}$ & $\mathbf{1}$ & $\mathbf{2}$ & $\mathbf{3}$ & $\mathbf{4}$ & $\mathbf{5}$ & $\mathbf{6}$ & $\mathbf{7}$ & $\mathbf{8}$ \\
AIC & $-2,40$ & $-2,45$ & $-2,52$ & $-2,62 *$ & $-2,60$ & $-2,58$ & $-2,56$ & $-2,54$ & $-2,39$ \\
SC & $-2,35$ & $-2,37$ & $-2,41$ & $-2,49 *$ & $-2,45$ & $-2,40$ & $-2,36$ & $-2,31$ & $-2,13$ \\
\hline
\end{tabular}

According to both criteria, three lags are sufficient to capture the dynamic relationship between operating revenues and customer satisfaction. An initial feasible GLS estimation of the so specified model yields the parameter estimates as presented in Table 3:

Table 3: Parameter estimates of the model

\begin{tabular}{|lccccc|}
\hline \multicolumn{5}{c|}{ Parameter Estimates } \\
\hline Variable & Coefficient & Std. Error & t-Statistic & Prob. & Adj. ${ }^{2}$ \\
$\Delta \ln \left(\mathrm{s}_{i, t-1}\right)$ & 0,111 & 0,097 & 1,143 & 0,26 & \\
$\Delta \ln \left(\mathrm{s}_{i, t-2}\right)$ & $-0,011$ & 0,094 & $-0,118$ & 0,91 & 0,539 \\
$\Delta \ln \left(\mathrm{s}_{i, t-3}\right)$ & 0,224 & 0,089 & 2,511 & 0,01 & \\
$\Delta \ln \left(\mathrm{a}_{t}\right)$ & 0,847 & 0,082 & 10,251 & 0,00 & \\
\hline
\end{tabular}

The results clearly show, that satisfaction has an impact on a bank's operating revenues. We find evidence for a lagged effect, that is positive, highly significant ( $\mathrm{p}$-value $=0,01$ ) and arises with a lag of three periods (i.e. 1,5 years). The coefficient on the proxy variable capturing the general conditions of the industry is also highly significant ( $\mathrm{p}$-value $<0,01$ ) and has the expected positive sign. The p-values of the coefficients on the two remaining lagged growth rates of customer satisfaction, however, suggest that these terms do not have any explanatory power, which indicates, that obviously more then a year has to pass by before changes in customer satisfaction have a measurable impact on revenues.

In order to test the restrictions, that both $\beta_{1}$ and $\beta_{2}$ are not significantly different from 0 we perform a Wald-Test:

${ }^{40}$ See Diebold (1998), p. 90. 
Table 4: Test statistics for the Wald-Test

\begin{tabular}{|cc|}
\hline Wald-Tests for $H_{0}: \beta_{1}=\beta_{2}=0$ \\
\hline Test statistic & p-value \\
1,874 & 0,392 \\
\hline
\end{tabular}

As $H_{0}$ cannot be rejected on all common confidence levels, the final model specification only includes a three-period lagged effect (i.e., 1,5 years) of satisfaction growth on revenue growth. Estimates of this model are given in Table 5.

Table 5: Parameter estimates for the restricted model

\begin{tabular}{|lccccc|}
\hline \multicolumn{5}{c|}{ Parameter Estimates } \\
\hline Variable & Coefficient & Std. Error & t-Statistic & Prob. & Adj. $\mathbf{R}^{\mathbf{2}}$ \\
$\Delta \ln \left(\mathbf{s}_{i, t-3}\right)$ & 0,209 & 0,079 & 2,627 & 0,010 & 0,559 \\
$\Delta \ln \left(\mathbf{a}_{t}\right)$ & 0,862 & 0,070 & 12,260 & 0,000 & \\
\hline
\end{tabular}

As hypothesized the effect of customer satisfaction on revenues is clearly positive. If there is a $1 \%$ rise in the growth rate of satisfaction, revenue growth will record a 0,209\% rise. Furthermore as changing customer satisfactions has to alter behavioral intentions before triggering a reaction in the sales records of a bank, a change in satisfaction - as expected - takes time to bring along a change in revenue growth. Only after 1,5 years, the positive consequences of satisfaction prevail. Therefore it comes as no surprise that the general fit of a model accounting for the dynamics in the relationship between customer satisfaction and revenue is higher than the fit for static models or for models, where the time-series are not long enough to allow a thorough examination of the relationship in question: The adjusted $\mathrm{R}^{2}$ is 0,559 and hence much higher than the corresponding fit measures of comparable studies done in Anderson/Fornell/Lehmann (weighted $\mathrm{R}^{2}$ for first difference specification is 0,35 ). and Bernhardt/Donthu/Kenneth (Correlation Coefficient between sales and lagged satisfaction is $+0,42$ ).

We also find a clear indication, that, as hypothesized in Anderson/Fornell/Lehmann (1994), customers have adaptive and rational expectations. "Changes in the level of quality provided by a firm enhance or erode a firm's reputation for quality over time. ... The implication for a firm trying to make a quality "turnaround" or "comeback" is, therefore, not to expect immediate returns ...."41

As for the managerial implications of these findings, it should be noted, that, generally speaking, customer satisfaction is an important variable worthwhile considering. A slump in customer satisfaction could for instance be used as an early warning signal for subsequent changes in sales figures. This would enable companies to react swiftly and in time to a potentially forthcoming erosion of their revenue figures. At the same time, our results dictate patience in the evaluation of customer satisfaction initiatives, as the impacts of these programs take time to become apparent.

\section{Conclusion}

Several studies have investigated the link between customer satisfaction and the financial performance of companies. The evidence on the long term effects of customer satisfaction is however relatively scarce. Furthermore, research has so far often estimated models for a mixture of different industries thus hiding potential industry idiosyncrasies. We investigate the total impact of customer satisfaction on operating revenues based on a longitudinal dataset for retail banks. Results indicate a positive long run effect of satisfaction on revenues. We

\footnotetext{
${ }^{41}$ See Anderson/Fornell/Lehmann (1994), p. 64.
} 
observe a time lag of 1,5 years for satisfaction to finally have a positive impact on sales, and this makes customer satisfaction a valid early warning signal for revenue figures. Therefore, as noted in Bernhardt/Donthu/Kennet (2000) “... time-series ... [are] valuable when attempting to uncover what is actually going on in the marketplace." ${ }^{42}$

Future research should on the one hand aim at extending our research design to other industries and on the other hand focus on the impact of satisfaction on firm value, ideally referring to capital market data.

\section{Literature}

1. Aaker, D.A. /Jacobson, R. (1994), The Financial Information Content of Perceived Quality, in: Journal of Marketing Research, Vol. 21, May 1994, pp. 191 - 201.

2. $\quad$ Amemiya, T. (1985), Advanced Econometrics, Harvard University Press, 1985.

3. Anderson, E.W. (1996), Customer Satisfaction and Price Tolerance, in: Marketing Letters, Vol. 7, No. 3, 1996, pp. $19-30$.

4. Anderson, E.W. /Fornell, C. /Lehmann, D.R. (1994), Customer Satisfaction, Market Share, and Profitability: Findings From Sweden, in: Journal of Marketing, Vol. 58, 1994, pp. 53 - 66.

5. Anderson, E.W. /Fornell, C. /Rust, R.T. (1997), Customer Satisfaction, Productivity, and Profitability: Differences Between Goods and Services, in: Marketing Science, Vol. 16, No. 2, 1997, pp. 129 - 145.

6. Anderson, E.W. /Sullivan, M. (1993), The Antecedents and Consequences of Customer Satisfaction for Firms, in: Marketing Science, Vol. 12, No. 2, 1993, pp. 125 - 143.

7. Anderson, T. /Hsiao, C. (1982), Formulation and Estimation of Dynamic Models Using Panel Data, in: Journal of Econometrics, Vol. 18, 1982, pp. $67-82$.

8. Bernhardt, K.L. /Donthu, N. /Kennet, P.A. (2000), A Longitudinal Analysis of Satisfaction an Profitability, in: Journal of Business Research, Vol. 47, 1999, pp. 176 - 171.

9. Birchard, B. (1994), The Call for Full Disclosure, Boston, 1994.

10. Boulding, W. (1990), Commentary on ' Unobservable Effects and Business Performance: Do Fixed Effects Really Matter?', in: Marketing Science, Vol. 9, pp. 88 - 91.

11. $\quad$ Buzzell, R.D. /Gale, B.T. (1987), The PIMS Principles, The Free Press, New York, 1987.

12. DeSarbo, W. / Huff, L. /Rolandelli, M.M. / Choi, J. (1994), On Measurement of Perceived Service Quality : A Conjoint Measurement Approach, in: Service Quality, Rust, R.T. /Oliver, R.W. (Eds.), Thousands Oaks, CA: Sage Press, 1994.

13. Dowling, G.R. /Uncles, M. (1997), Do Customer Loyalty Programs Really Work?, in: Sloan Management Review, Summer 1997, pp. $71-82$.

14. Dull, S. (1998), Marketing's impact on financial performance often overlooked, in: Pulp \& Paper, September 1998, pp. $55-67$.

15. Fischer, H. /Hermann, A. /Huber, F. (2001), Return on Customer Satisfaction, in: ZfB, 71. Jg., No. 10, 2001, pp. $1161-1190$.

16. Fishbein, M. /Ajzen, I (1975), Belief, Attitude, Intention, and Behavior, Reading, MA: Addison-Wesley, 1975.

17. Fornell, C. (1992), A National Customer Satisfaction Barometer: The Swedish Experience, in: Journal of Marketing, Vol. 56, January 1992, pp. 6 - 21.

18. Fornell, C. /Johnson, M.D. /Anderson, E.W /Cha, J. /Bryant, B. E. (1996), The American Customer Satisfaction Index: Nature, purpose, and findings, in: Journal of Marketing, Vol. 60, Iss. 4; 1996 pp. 7-12

19. Garvin, D.A. (1988), Managing Quality: The Strategic and Competitive Edge, The Free Press, New York, 1988.

20. Granger, C. /Newbold, P. (1974), Spurious Regressions in Econometrics, in: Journal of Econometrics, Vol. 2, 1974, pp. $111-120$.

21. Greene, W.H. (2000), Econometric Analysis, 4th edition, Prentice Hall International, 2000.

22. $\quad$ Griliches, Z. (1971), Price Indices and Quality Change, Harvard University Press, 1971.

23. Grunfeld, Y. /Griliches, Z. (1960), Is Aggregation Necessarily Bad?” in: Review of Economics and Statistics, Vol. 42, 19960, pp. $1-13$.

24. Harvey, A. (1990), The Econometric Analysis of Time Series, $2^{\text {nd }}$ Edition, The MIT Press, 1990.

25. Hermann, A. /Johnson, M.D. (1999), Die Kundenzufriedenheit als Bestimmungsfaktor der Kundenbindung, in: ZfbF, Vol. 51, 1999, pp. $579-598$.

\footnotetext{
${ }^{42}$ See Bernhardt/Donthu/Kennet (2000), p.170.
} 
26. Hill, R. C. (1993), When the Going Gets Rough: A Baldridge Award Winner On the Line, in: Academy of Management Executive, Vol. 7, August 1993, pp. 75 - 79.

27. Homburg, C. (1998), Kundennähe von Industriegüterunternehmen: Konzeption - Erfolgswirkungen Determinanten, 2. Aufl., Wiesbaden, 1998.

28. Holtz-Eakin, D. /Newey, W. /Rosen, H. (1988), Estimating Vector Autoregressions with Panel Data, in: Econometrica, Vol. 56, Iss. 6, 1988, pp. $1371-1395$.

29. Johnson, M.D. (1995), Comparability in Customer Satisfactions Surveys: Products, Services, and Government Agencies, Seminar on new Directions in statistical Methodology: Volume 1, Washington, Statistical Policy Working Paper, No. 23, pp. $99-120$.

30. Johnson, M.D. (1998), Customer Orientation and Market Action, New Jersey, 1998.

31. Jorgenson, D. (1996), Rational Distributed Lag Functions, in: Econometrica, Vol. 34, 1966, pp. 135 - 149.

32. Keiningham, T. /Zahorik, A.J. /Rust, R.T. (1994), Getting Return On Quality, in: Journal of Retail Banking, Vol. 16, No. 4, 1994, pp. 7 - 12.

33. LaBarbera, P.A. /Mazursky, D. (1983), A Longitudinal Assessment of Consumer Satsifaction/Dissatisfaction: The Dynamic Aspect of the Cognitive Process, in: Journal of Marketing Research, Vol. 20, November 1983, pp. 393 404.

34. Licata, J.W. /Weber, J.M. /reed, P.F. (1998), Satisfaction Surveys: Staying on the Right Side of the Tracking, in: Bank Marketing, December 1998, pp. 26 -31.

35. Loro, L. (1992), Consumer is Always Right, in: Advertising Age, February 10, 1992, pp. 25.

36. Mittal, V. /Kamakura, W.A. (2001), Satisfaction, Repurchase Intent, and Repurchase Behavior: Investigating the Moderating Effect of Customer Characteristics, in: Journal of Marketing Research, Vol. 28, Feb. 2001, pp. 131 142.

37. Mittal, V. /Ross, W.T. /Baldasare, P.M. (1998), The Asymmetric Impact of Negative and Positive Attribute-Level Performance on Overall Satisfaction and Repurchase Intentions, in: Journal of Marketing, Vol. 62, January 1998, pp. $33-47$.

38. Mohs, J. (1999), Frequency Marketing, in: Retail Report, Vol. 12, No. 4, 1999, pp. 3.

39. Nair-Reichert, U. /Weinhold, D. (2001), Causality Tests for Cross-Country Panels: New Look at FDI and Economic Growth in Developing Countries, in: Oxford Bulletin of Economics and Statistics, Vol. 63, Iss. 2, pp. $153 \mathrm{ff}$.

40. Nelson, E. /Rust, R.T. /Zahorik, A. /Rose, R.L. /Batalden, P. /Siemanski, B. A. (1992), Do Patient Perceptions of Quality Relate to Hospital Financial Performance?, in: Journal of Health Care Marketing, Vol. 13, December 1992, pp. $1-13$.

41. OeNB Oesterreichische Nationalbank (Eds.) (1989a), Statistisches Monatsheft, No. 6, 1989.

42. OeNB Oesterreichische Nationalbank (Eds.) (1989b), Statistisches Monatsheft, No. 12, 1989.

43. OeNB Oesterreichische Nationalbank (Eds.) (1990a), Statistisches Monatsheft, No. 6, 1990.

44. OeNB Oesterreichische Nationalbank (Eds.) (1990b), Statistisches Monatsheft, No. 12, 1990.

45. OeNB Oesterreichische Nationalbank (Eds.) (1991a), Statistisches Monatsheft, No. 6, 1991.

46. OeNB Oesterreichische Nationalbank (Eds.) (1991b), Statistisches Monatsheft, No. 12, 1991.

47. OeNB Oesterreichische Nationalbank (Eds.) (1992a), Statistisches Monatsheft, No. 6, 1992.

48. OeNB Oesterreichische Nationalbank (Eds.) (1992b), Statistisches Monatsheft, No. 12, 1992.

49. OeNB Oesterreichische Nationalbank (Eds.) (1993a), Statistisches Monatsheft, No. 6, 1993.

50. OeNB Oesterreichische Nationalbank (Eds.) (1993b), Statistisches Monatsheft, No. 12, 1993.

51. OeNB Oesterreichische Nationalbank (Eds.) (1994a), Statistisches Monatsheft, No. 6, 1994.

52. OeNB Oesterreichische Nationalbank (Eds.) (1994b), Statistisches Monatsheft, No. 12, 1994.

53. OeNB Oesterreichische Nationalbank (Eds.) (1995a), Statistisches Monatsheft, No. 6, 1995.

54. OeNB Oesterreichische Nationalbank (Eds.) (1995b), Statistisches Monatsheft, No. 12, 1995.

55. OeNB Oesterreichische Nationalbank (Eds.) (1996a), Statistisches Monatsheft, No. 6, 1996.

56. OeNB Oesterreichische Nationalbank (Eds.) (1996b), Statistisches Monatsheft, No. 12, 1996.

57. OeNB Oesterreichische Nationalbank (Eds.) (1997a), Statistisches Monatsheft, No. 6, 1997.

58. OeNB Oesterreichische Nationalbank (Eds.) (1997b), Statistisches Monatsheft, No. 12, 1997.

59. OeNB Oesterreichische Nationalbank (Eds.) (1998a), Statistisches Monatsheft, No. 6, 1998.

60. OeNB Oesterreichische Nationalbank (Eds.) (1998b), Statistisches Monatsheft, No. 12, 1998.

61. OeNB Oesterreichische Nationalbank (Eds.) (1999a), Statistisches Monatsheft, No. 6, 1999.

62. OeNB Oesterreichische Nationalbank (Eds.) (1999b), Statistisches Monatsheft, No. 12, 1999. 
63. Oesterreichische Nationalbank (Eds.) (1999), Gesamtwirtschaftliche Finazierungsrechnung gemäß ESVG 95, Geldvermögens- und Verpflichtungsstände der Österreichischen Volkswirtschaft, Ergebnisse für das Jahr 1999, 1999.

64. OeNB Oesterreichische Nationalbank (Eds.) (2000a), Statistisches Monatsheft, No. 6, 2000.

65. OeNB Oesterreichische Nationalbank (Eds.) (2000b), Statistisches Monatsheft, No. 12, 2000.

66. OeNB Oesterreichische Nationalbank (Eds.) (2001a), Statistisches Monatsheft, No. 6, 2001.

67. OeNB (2001b), Anweisungsrichtlinien zum Quartalsbericht (QUAB) gem §64 und §79 Bankwesengesetz, Juni 2001.

68. Oliver, R.L. (1977), Effects of Expectations and Disconfirmation on Postexposure Product Evaluations, in: Journal of Applied Psychology, Vol. 62, April 1977, pp. 246 - 250.

69. Peterson, R.A. /Wilson, W.R. (1992), Measuring Customer Satisfaction: Fact and Artefact, in: Journal of the Academy of Marketing Science, Vol. 20, Winter 1992, pp. 61 - 71.

70. Philips, P. (1986), Understanding Spurious Regressions, in: Journal of Econometrics, Vol. 33, 1986, pp. 311 340.

71. Rose, S. (1990), The Coming Revolution in Credit Cards, in: Journal of Retail Banking, Vol. 12, Summer 1990, pp. $17-19$.

72. Rucci, A.J. /Kirn, S.P. /Quinn, R.T. (1998), The employee-customer-profit chain at Sears, in: Harvard Business Review, January-February 1998, pp. 83 - 97.

73. Runow, H. (1982), Zur Theorie und Messung der Verbraucherzufriedenheit, Barudio \& Hess Verlag, Frankfurt am Main, 1982.

74. Rust, R.T. /Zahorik, A.J. (1993), Customer Satisfaction, Customer Retention, and Market Share, in: Journal of Retailing, Vol. 69, Summer 1993, pp. 145 - 156.

75. Rust, R.T. /Zahorik, A.J. /Keinigham, T.L. (1994), Return on Quality: Measuring the Financial Impact of Your Company's Quest for Quality, Probus, Chicago, 1994.

76. Rust, R.T. /Zahorik, A.J. /Keinigham, T.L. (1995), Return on Quality (ROQ): Making Service Quality Financially Accountable, in: Journal of Marketing, Vol. 59, April 1995, pp. 58 - 70.

77. Schneider, B. (1991), Service Quality and Profits: Can You Have Your Cake and Eat It Too?, in: Human Resource Planning, Vol. 14, 1991, pp. 151 - 157.

78. Shoultz, D. (1989), Service Firms Are Customer Driven: Study, in: American Banker, February 23, 1989, pp. 17 18.

79. Swan, J.E. /Martin, W.S. (1981), Testing Comparison Levels and Predictive Expectations Models of Satisfaction, in: Advances in Consumer Research, K. Monroe (Eds.), Association for Consumer Research, pp. 77 - 82.

80. TARP/Technical Assistance Research Program (1979), Consumer Complaint Handling In America: Final Report, United States Department of Health, Education, and Welfare, Washington, D.C., 1979.

81. TARP/Technical Assistance Research Program (1981), Measuring the Grapevine: Consumer Response and Wordof-Mouth, The Coca-Cola Co., Atlanta, 1986.

82. TARP/Technical Assistance Research Program (1986), Consumer Complaint Handling In America: An Update Study, United States Department of Health, Education, and Welfare, Washington, D.C., 1986.

83. Thomas, J. (1998), Avoiding Data Trunctation Bias in Customer Lifetime Analysis, Working Paper, Stanford University.

84. Tornow, W.W. /Wiley, J.W. (1991), Service Quality and Management Practices: A Look at Employee Attitudes, Customer Satisfaction, and Bottom-Line Consequences, in: Human Ressource Planning, Vol. 14, 1991, pp. 105 115.

85. Westbrook, R. A. (1980), A Rating Scale for Measuring Product/Service Satisfaction, in: Journal of Marketing, Vol. 44, Fall 1980, pp. $68-72$.

86. Wooldridge, J. M. (2000), Introductory Econometrics - A Modern Approach, South-Western College Publishing, 2000.

87. Wooldridge, J. M. (2002), Econometric Analysis of Cross Section and Panel Data, The MIT Press, 2002.

88. Zeithaml, V. /Parasuraman, A. /Berry, L.L. (1990), Delivering Quality Service, The Free Press, New York, 1990. 